\title{
POLYMORPHISM IN THE MIMETIC BUTTERFLY HYPOLIMNAS MISIPPUS L. IN GHANA
}

\author{
M. EDMUNDS \\ Department of Zoology, University of Ghana, Legon, Ghana
}

Received 20.vii.68

\section{INTRODUCTION}

Hypolimnas misippus L. is a well-known African nymphalid butterfly in which the male has a black and white pattern whilst the female is a mimic of the common danaid butterfly Danaus chrysippus L. Illustrations of both species and descriptions of the mimetic association can be found in Eltringham (1910), Punnett (1915), Stride (1956) and Ford (1964). In Ghana, Danaus chrysippus is monomorphic belonging to the form alcippus in which the orange fore wing is tipped with black and white, whilst the hind wing is almost entirely white. Three forms of $H$. misippus occur in Ghana (Stride, 1956): the typical urof, misippus, has orange fore wings tipped with black and white, and orange hind wings (resembling the typical form of Danaus chrysippus); form inaria has the black and white of the fore wings replaced by orange (resembling the dorippus form of $D$. chrysippus); and form alcippoides has some of the orange on the hind wing replaced by white (resembling the alcippus form of $D$. chrysippus). Ford (1964) has shown that the inaria form is recessive to misippus and there is evidence suggesting that the recessives are less viable than either the dominant homozygotes or the heterozygotes. The genetic control of the alcippoides form has not been studied, but it is probably polygenic. Forms intermediate between typical misippus and typical inaria have been reported (Leigh, 1904; Carpenter and Ford, 1933; Stride, 1956), and these occur commonly at Legon, Ghana. All intermediates can be found between forms with orange hind wings and forms with almost entirely white hind wings. Some of these insects with white hind wings have black and white tipped fore wings (form alcippoides), some have orange tipped fore wings, and in some the tip of the fore wing is intermediate with some black and white amongst the orange pigment.

If the association between Hypolimnas misippus and Danaus chrysippus in Ghana is mimetic, then one would expect the survival rate and frequency of the alcippoides form to vary with the abundance of the model. The survival rates of the other morphs should not be affected by the presence or absence of Danaus since they do not resemble it at all closely.

\section{Method of Study}

The population of Hypolimnas misippus and Danaus chrysippus was studied near the Zoology Department of the University of Ghana, Legon, during the rainy seasons of 1965 and 1966 when the insects are more abundant than at other times of the year. Insects were collected from an area approximately 150 metres square comprising low buildings, regularly cut grassland with scattered shrubs, and much rougher weedy grassland which is cut only 
occasionally. Except at the beginning of the study a regular route was followed through this area. Insects caught were marked and released as described by Fisher and Ford (1947) and Parr (1965), except that they were released a few seconds after marking close to the point of capture instead of at a central point. The few recaptures on the day of marking have not been included in the survival rate computations.

The colour pattern of all insects caught was scored in the following way. The area near the tip of the fore wing in typical forms is black and white
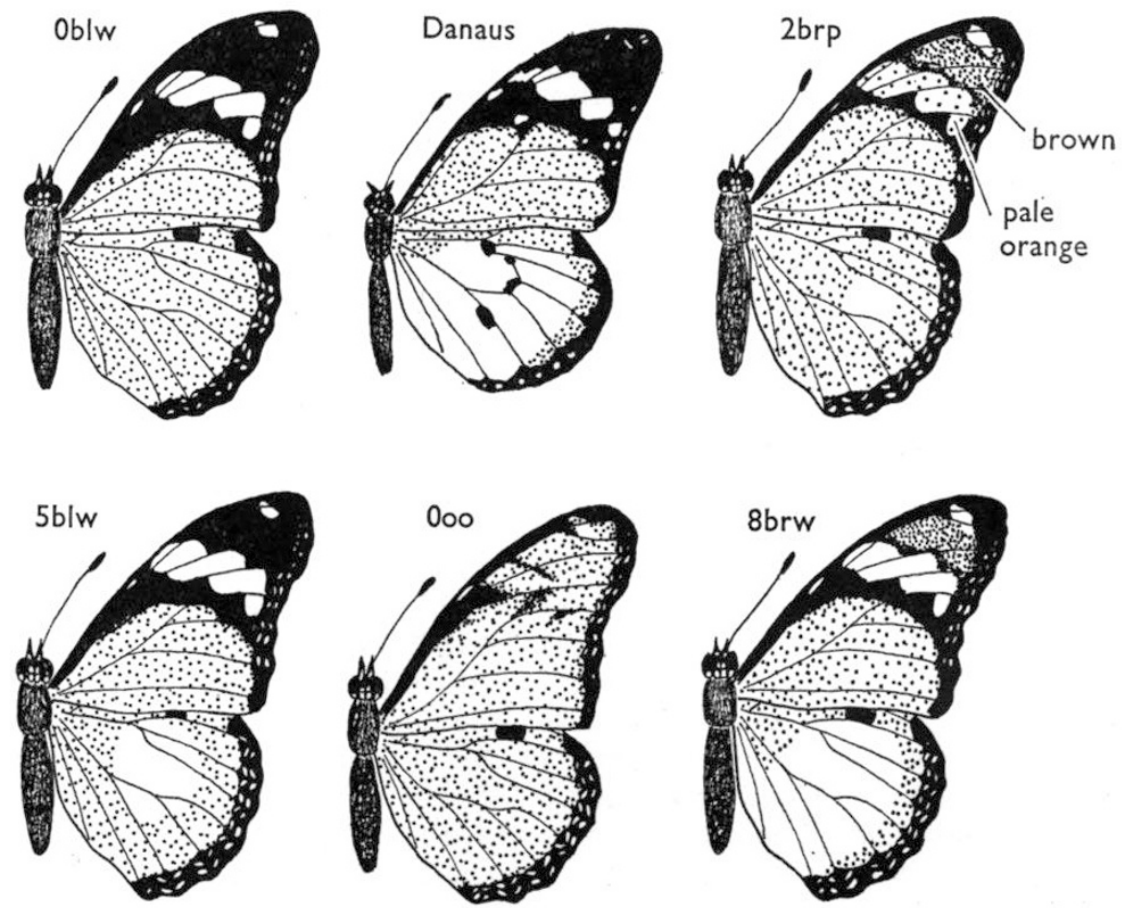

FIG. 1.-Some of the colour forms of Hypolimnas misippus and Danaus chrysippus found at Legon, Ghana. Black and white markings are as shown, orange areas are stippled, brown is densely stippled, and pale orange is sparsely stippled. Oblw is the typical misippus form of Hypolimnas; 0oo is the inaria form; $5 \mathrm{blw}$ is the alcippoides form; and $2 \mathrm{brp}$ and $8 \mathrm{brw}$ are intermediate between the three forms. The Danaus shown belongs to form alcippus, and can be scored as $7 \mathrm{blw}$.

(scored as blw), but in inaria both colours are replaced by orange (oo) (fig. 1). If the black is sparse and overlies orange, the appearance is brown (br), and if the white contains a few orange scales it appears pale orange (p). On the hind wings the colour is normally uniformly orange with no white $(0)$, but if white is present, the number of interveins covered by the white patch is counted (see fig. 1). In the model the whole of the hind wing is occasionally white giving a score of 10 , but the maximum score observed in $H$. misippus was 8 . If the orange hind wings are faintly suffused with white, the insect is compared with typical forms with $0,1,2$, etc., on the hind wing and assigned to the category it most closely resembles in appearance. In fig. 1, Oblw is a typical misippus insect, 0oo is inaria, 5blw is alcippoides, and $2 \mathrm{brp}$ and $8 \mathrm{brw}$ are two of the many different intermediate patterns. 
Except at the beginning of the 1965 season, insects which were caught in perfect condition were marked differently from worn insects. They had almost certainly emerged only a few hours before capture since if recaptured one or two days later their appearance was much worn. It is therefore reasonable to assume that these fresh insects had not been subjected to the same selection pressures that affected old and worn insects.

TABLE 1

Numbers of female Hypolimnas misippus with different hind wing patterns

\begin{tabular}{|c|c|c|c|c|c|c|c|c|c|}
\hline \multirow[b]{3}{*}{ Number of insects caught in: } & \multicolumn{9}{|c|}{ Amount of white on hind wing } \\
\hline & 0 & 1 & 2 & 3 & 4 & 5 & 6 & 7 & 8 \\
\hline & & & & & & & & & \\
\hline 1965 & 165 & 5 & 13 & 9 & 9 & 1 & 1 & 4 & 1 \\
\hline 1966 & 133 & 15 & 11 & 6 & 7 & 3 & 1 & 0 & 3 \\
\hline Total & 298 & 20 & 24 & 15 & 16 & 4 & 2 & 4 & 4 \\
\hline
\end{tabular}

\section{ABUndance of Different MORPhS IN 1965 AND 1966}

Table 1 gives the total numbers of female $H$. misippus caught in the two seasons with different amounts of white on the hind wing. Table 2 compares the amount of white on the hind wing of $H$. misippus with that found in Danaus chrysippus in 1966. To the human eye, insects with four or more interveins crossed with white have an appearance of white, and presumably these are the mimics that are most easily confused with $D$. chrysippus, and hence best protected in nature.

TABLE 2

Percentages of 387 female Hypolimnas misippus and of 229 Danaus chrysippus (both sexes) with different amounts of white on the hind wing

\begin{tabular}{|c|c|c|c|c|c|c|c|c|c|c|c|}
\hline & \multicolumn{11}{|c|}{ Amount of white on hind wing } \\
\hline & 0 & 1 & 2 & 3 & 4 & 5 & 6 & 7 & 8 & 9 & 10 \\
\hline 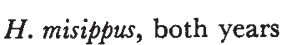 & $77 \cdot 1$ & $5 \cdot 2$ & $6 \cdot 2$ & 3.9 & $4 \cdot 1$ & $1 \cdot 0$ & 0.5 & $1 \cdot 0$ & $1 \cdot 0$ & 0.0 & $0 \cdot 0$ \\
\hline D. chrysippus, 1966 & 0.0 & 0.0 & 0.0 & 0.0 & $0 \cdot 0$ & $2 \cdot 2$ & $20 \cdot 1$ & $63 \cdot 3$ & $10 \cdot 5$ & $2 \cdot 2$ & $1 \cdot 7$ \\
\hline
\end{tabular}

The small number of insects with a score of 1 on the hind wing in 1965 (table 1) is significantly different from the 1966 figures when this category is scored against all others $\left(\chi_{(1)}^{2}=5 \cdot 844, P<0 \cdot 02\right)$. This may be due to inconsistency of the scoring method in the two seasons, or it may reflect a change in the frequency of this class in the two years. If the insects with some white present are united, and contrasted with those with no white, there is no significant difference in the proportion of insects with white present in the two seasons $\left(x_{(1)}^{2}=1 \cdot 103,0.3>P>0 \cdot 2\right)$. For subsequent analysis of seasonal changes in morph frequency all insects with some white present are pooled, on the assumption that even a small amount of white may be of some protective value to the insect.

Table 3 gives the numbers of female $H$. misippus with different fore wing patterns caught in the two seasons. The figures are very similar for the two years except for the increase in the op class in 1966. This is significant when op is scored against all other classes combined $\left(\chi_{(1)}^{2}=6.820, \mathrm{P}<0 \cdot 01\right)$. 
This probably represents a real change in the frequency of this morph since the other classes which might be confused with op show no deficiency in 1966: thus there is no evidence for inconsistency of scoring method.

TABLE 3

Numbers of female Hypolimnas misippus with different fore wing patterns

Number caught in 1965

Number caught in 1966

\begin{tabular}{lcccccc}
\multicolumn{8}{c}{ Fore wing pattern } \\
blw & brp & brw & bro & ow & op & oo \\
161 & 11 & 1 & 9 & 1 & 3 & 22 \\
132 & 9 & 2 & 3 & 0 & 13 & 20 \\
293 & 20 & 3 & 12 & 1 & 16 & 42
\end{tabular}

Table 4 compares the presence or absence of white on the hind wing with the fore wing pattern. Two conclusions emerge from this table; firstly, a significantly smaller proportion of oo insects (inaria) have white on the hind wing than do blw (misippus). Second, a significantly higher proportion of the "other types" have white on the hind wing than do either blw or oo.

TABLE 4

Correlation between fore wing and hind wing pattern in female Hypolimnas misippus

\begin{tabular}{lccc}
\multirow{2}{*}{$\begin{array}{l}\text { Fore wing type } \\
\text { blw }\end{array}$} & Date & White absent & White present \\
Total & 1965 & 128 & 33 \\
& 1966 & 99 & 33 \\
oo & & 227 & $66(22.5 \%)$ \\
Total & 1965 & 19 & 3 \\
other types & 1966 & 19 & 1 \\
Total & 1965 & 38 & $4(9.5 \%)$ \\
$\chi_{(1)}^{2}$ comparing blw with oo & 18 & 7 \\
$\chi_{(1)}^{2}$ comparing blw with other types $=3.946, \mathrm{P}<0.05$ \\
$\chi_{(1)}^{2}$ comparing oo with other types $=4.155^{*}, \mathrm{P}<0.05$
\end{tabular}

* This, and all other $\chi^{2}$ derived from $2 \times 2$ tables, involve the use of Yates' correction. In this particular case the expected number of whites is very small. Using the exact treatment (Fisher, 1958), $\mathrm{P}=0.00205$.

Thus the insects one is most likely to find with white on the hind wing are those which are intermediate between typical inaria and typical misippus in fore wing pattern. Presumably the genes responsible for white on the hind wing also modify the expression of the genes controlling fore wing colour. The "other types" category in table 4 includes some insects which are undoubtedly genetically inaria (op for example) and others that are presumably misippus (such as brw). If the brw and brp are added to the blw 
category of table 4, and the remaining types are added to the oo category, we obtain the figures shown in table 5 . There is no significant difference in the frequency of forms with white on the hind wing amongst the two classes. Thus the genes controlling fore wing and hind wing colours are not linked.

\section{The size of the Population AND SEX RATio}

The study area was not a closed population, so estimates of survival rate and population size will include a certain amount of emigration and immigration. The population estimates are calculated by the method of Fisher and Ford as described by Parr (1965), and are the product of the estimated number of marks in the population and the captures, divided by the recaptures. Because of the low number of recaptures, five day moving averages were taken. Figure 2 shows the population estimates of male and female Hypolimnas misippus and of Danaus chrysippus (both sexes combined) for 1965. The female Hypolimnas population estimate is derived from the total population estimate of both sexes minus the estimated male population.

TABLE 5

Correlation between fore wing and hind wing pattern in female Hypolimnas misippus

\begin{tabular}{lccc} 
Fore wing type & \multicolumn{3}{c}{ Hind wing type } \\
\cline { 2 - 4 } $\begin{array}{c}\text { White } \\
\text { absent }\end{array}$ & $\begin{array}{c}\text { White } \\
\text { present }\end{array}$ & $\begin{array}{c}\text { Percentage } \\
\text { with white }\end{array}$ \\
blw, brw, brp & 242 & 74 & 23.4 \\
oo, bro, ow, op & 56 & 15 & 21.2
\end{tabular}

This method gives more consistent day-to-day figures than do estimates based on the female survival rate, since there are several five-day periods during which there was only one female recaptured. Population estimates for these days are obviously unreliable since a single additional recapture would decrease the estimate by 50 per cent. By taking the total population of both sexes and subtracting the estimated number of males, this defect is, to some extent, avoided.

Figure 2 also shows that from 17th May until the first week of June there were considerably more males than females in the population of Hypolimnas (56-86 per cent. males). From the first week of June until collection ceased in July, the sex ratio was close to equality. The sex ratio of insects caught during five-day periods also declined from 62-71 per cent. males before 14th June to 51-58 per cent. males after 14th June. Since the males are slightly easier to catch than the females, the sex ratio never quite diminished to 50 per cent. Thus the sex ratio may depart significantly from equality, but it never reaches the extreme values found in Acraea encedon L. by Owen $(1965 a)$.

In 1965 it was found that fewer female Hypolimnas were collected in the early morning than later on, so in 1966 collection was restricted to one hour each day, between 10.00 and 11.00 a.m. local time (= G.M.T.). The recapture rate was very low, so population estimates are unreliable, but again the population was high initially, then fell to a low level, and fluctuated about this level until collection ceased in July. A population index 
based on the number of insects captured per hour shows a similar pattern. Males were not captured in 1966, so no observations were made on sex ratio.

\section{SuRvival RATES OF DifFERENT MORPHS}

In order to study seasonal changes in the frequency of different morphs, it is necessary to combine some of the rarer classes together so that the figures become sufficiently large for significant changes to be detected. On

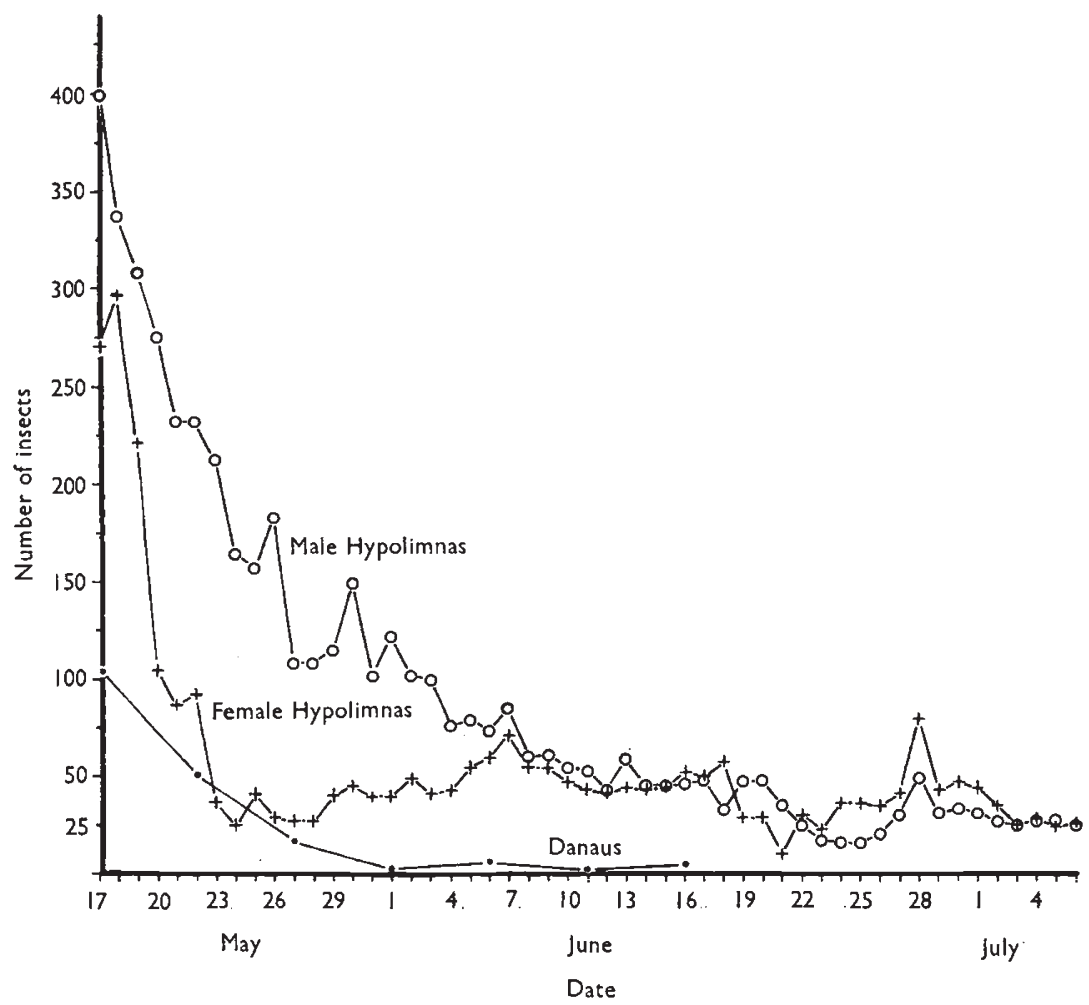

Fig. 2.-Five day moving average population estimates of male and female Hypolimnas misippus and of Danaus chrysippus. The male estimates are based on a survival rate of $0 \cdot 649$. The female estimates are based on the population estimate of both sexes combined (survival rate 0.6432 ) minus the estimated male population. The Danaus estimates are based on a survival rate of 0.775 . These survival rates differ slightly from those given in table 6 which only cover the period 21 st May to 7 th July 1965.

the hind wing, all insects with any white at all are classed as "white", and the rest are called " orange" (equivalent to "white present" and "white absent" respectively in table 4). On the fore wing, blw, brw and brp are classed together as misippus, whilst oo, op, ow and bro are classed together as inaria. Very similar results are obtained if the blw class is contrasted with all other forms combined.

Survival rates and population parameters can be computed in a number of different ways (Parr, 1965; Southwood, 1966), but the most suitable method for the present data, in which the recapture rate is low, is that of Fisher and Ford (1947). Survival rates were computed to only the third 
figure, and confidence limits were calculated following the method of Leslie and Chitty (1951).

Table 6 gives the survival rates of the various classes of Hypolimnas for 1965 and 1966 together with their 95 per cent. confidence limits. The variance of the figures is high because of the small numbers of recaptures, but the following conclusions can be drawn:

1. The survival rate of females was approximately the same for both 1965 and 1966, and was almost identical with that of males in 1965.

2. The survival rate increased from about 40 per cent. per day in the first half of the season to about 70 per cent. in the second half in both 1965 and 1966. The difference is not significant, but since the figures are almost identical in both years this probably represents a real improvement in survival as the season progresses.

TABLE 6

Survival rates for Hypolimnas misippus, 1965 and 1966

Season

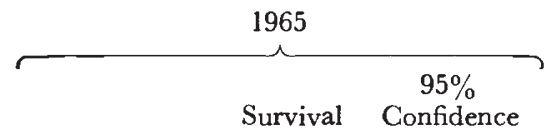

Category

Males

All females

All females

All females

Orange

White

misippus

inaria

$\begin{array}{lcc}\text { Date } & \begin{array}{c}\text { Survival } \\ \text { rate (S) }\end{array} & \begin{array}{c}\text { Confidence } \\ \text { intervals }\end{array} \\ \text { 21 May-7 July } & 0.649 & (0.592-0 \cdot 706) \\ \text { 21 May-7 July } & 0.650 & (0.550-0.750) \\ & & \\ \text { 21 May-10 June } & 0.445 & (0.011-0.879) \\ \text { 11 June-7 July } & 0.722 & (0.266-0.988) \\ \text { 21 May-7 July } & 0.709 & (0.558-0.860) \\ \text { 21 May-7 July } & 0.205 & (0.0-0.482) \\ & & \\ \text { 21 May-7 July } & 0.601 & (0.477-0.725) \\ \text { 21 May-7 July } & 0.788 & (0.618-0.958)\end{array}$

$\begin{array}{ccc}\text { Date } & \begin{array}{c}\text { Survival } \\ \text { rate }(\mathrm{S})\end{array} & \begin{array}{c}95 \% \\ \text { Confidence } \\ \text { intervals }\end{array} \\ - & - & - \\ \text { 19 April-20 July } & 0.665 & (0.566-0 \cdot 764) \\ \text { 19 April-9 June } & 0.396 & (0 \cdot 289-1 \cdot 0) \\ \text { 10 June-20 July } & 0.731 & (0 \cdot 532-0.930) \\ \text { 19 April-20 July } & 0.635 & (0 \cdot 501-0.769) \\ \text { 19 April-20 July } & 0.697 & (0 \cdot 427-0.967) \\ \text { 19 April-20 July } & 0.636 & (0 \cdot 417-0 \cdot 855) \\ \text { 19 April-20 July } & 0.850 & (0.520-1 \cdot 0)\end{array}$

3. The survival rate of orange females was approximately the same for both years, but the survival rate of whites was much lower in 1965 than in 1966. In 1966 there is no significant difference between the survival rates of orange and white insects, but in 1965 the whites survived significantly less well than the orange.

4. There is no significant difference in the survival rates of misippus and inaria in the two years. However, in both years misippus has a survival rate of about 60 per cent. per day whilst inaria has a survival rate of about 80 per cent. Because of this consistency, it is likely that there is in fact a difference in survival rate between the two morphs.

Expectations of life $(E)$ for the various classes of Hypolimnas are given in table 7. $E_{1}=1 /(1-S)$, where $S$ is the survival rate; $E_{2}=D / R$, where $D$ is the sum of the days survived of all the recaptures and $R$ is the number of individuals recaptured; $E_{3}=1 /-\log e^{S}$. $E_{3}$ probably gives the most accurate figure (Cook, Brower and Croze, 1967).

It is possible to calculate a selective value $(V)$ from the expectations of life from the ratio $V=E$ white $/ E$ orange. For 1965 this gives a selective value of 0.366 , or we can say that white is at a 63 per cent. disadvantage 
compared with orange, with 95 per cent. confidence limits at 14 and 86 per cent. This figure is obtained from $E_{1}$ of table 7 and is useful because it is possible to attach confidence limits to it. However, the selective value derived from $E_{3}$ may be a more accurate figure; this shows white to be an 82 per cent. disadvantage compared to orange.

TABLE 7

Expectation of life in days of Hypolimnas misippus calculated by three different methods (see text)

\begin{tabular}{|c|c|c|c|c|c|c|c|c|}
\hline \multirow[b]{2}{*}{ Category } & \multicolumn{4}{|c|}{1965} & \multicolumn{4}{|c|}{1966} \\
\hline & Date & $E_{1}$ & $E_{2}$ & $\overrightarrow{E_{3}}$ & Date & $E_{1}$ & $E_{2}$ & \\
\hline $\begin{array}{l}\text { All females } \\
\text { All females }\end{array}$ & $\begin{array}{l}21 \text { May-10 June } \\
11 \text { June-7 July }\end{array}$ & $\begin{array}{l}1 \cdot 80 \\
3 \cdot 60\end{array}$ & $\begin{array}{l}1.88 \\
3.47\end{array}$ & $\begin{array}{l}1.24 \\
3.07\end{array}$ & $\begin{array}{l}19 \text { April-9 June } \\
10 \text { June-20 July }\end{array}$ & $\begin{array}{l}1.66 \\
3.72\end{array}$ & $\begin{array}{l}1.71 \\
3.59\end{array}$ & \\
\hline $\begin{array}{l}\text { Orange } \\
\text { White }\end{array}$ & $\begin{array}{l}21 \text { May-7 July } \\
21 \text { May-7 July }\end{array}$ & $\begin{array}{l}3.44 \\
1.26\end{array}$ & $\begin{array}{l}3.44 \\
1.55\end{array}$ & $\begin{array}{l}2 \cdot 91 \\
0 \cdot 63\end{array}$ & $\begin{array}{l}19 \text { April-20 July } \\
19 \text { April-20 July }\end{array}$ & $\begin{array}{l}2 \cdot 74 \\
3 \cdot 30\end{array}$ & $\begin{array}{l}2 \cdot 83 \\
3 \cdot 33\end{array}$ & \\
\hline $\begin{array}{l}\text { misippus } \\
\text { inaria }\end{array}$ & $\begin{array}{l}21 \text { May-7 July } \\
21 \text { May-7 July }\end{array}$ & $\begin{array}{l}2 \cdot 51 \\
4 \cdot 72\end{array}$ & $\begin{array}{l}2 \cdot 56 \\
4 \cdot 22\end{array}$ & $\begin{array}{l}1 \cdot 96 \\
4 \cdot 20\end{array}$ & $\begin{array}{l}19 \text { April-20 July } \\
19 \text { April-20 July }\end{array}$ & $\begin{array}{l}2 \cdot 75 \\
6 \cdot 67\end{array}$ & $\begin{array}{l}2 \cdot 68 \\
3 \cdot 75\end{array}$ & \\
\hline
\end{tabular}

TABLE 8

Hypolimnas misippus: marks recaptured as a percentage of marks released for orange and white

\begin{tabular}{|c|c|c|c|c|c|c|c|c|c|}
\hline \multirow[b]{2}{*}{ Date } & \multicolumn{2}{|c|}{ Orange } & \multicolumn{2}{|c|}{ White } & \multicolumn{2}{|c|}{ Percentage } & \multirow[b]{2}{*}{$x_{(1)}^{2}$} & \multicolumn{2}{|c|}{ Days survived } \\
\hline & rec & rel & rec & rel & Orange & White & & Orange & White \\
\hline $\begin{array}{l}21 \text { May-7 July } 1965 \\
19 \text { April-20 July } 1966\end{array}$ & $\begin{array}{l}26 \\
23\end{array}$ & $\begin{array}{l}176 \\
147\end{array}$ & $\begin{array}{l}13 \\
12\end{array}$ & $\begin{array}{l}52 \\
53\end{array}$ & $\begin{array}{l}14 \cdot 8 \\
15 \cdot 7\end{array}$ & $\begin{array}{l}25 \cdot 0 \\
22 \cdot 6\end{array}$ & $\begin{array}{l}2 \cdot 284 \\
0.880\end{array}$ & $\begin{array}{l}3 \cdot 39 \\
2 \cdot 61\end{array}$ & $\begin{array}{l}1 \cdot 77 \\
3 \cdot 17\end{array}$ \\
\hline $\begin{array}{l}21 \text { May-24 June } 1965 \\
25 \text { June-7 July } 1965\end{array}$ & $\begin{array}{l}13 \\
12\end{array}$ & $\begin{array}{r}118 \\
58\end{array}$ & $\begin{array}{r}11 \\
2\end{array}$ & $\begin{array}{r}43 \\
9\end{array}$ & $\begin{array}{l}11 \cdot 0 \\
20 \cdot 7\end{array}$ & $\begin{array}{l}25 \cdot 6 \\
22 \cdot 2\end{array}$ & $\stackrel{4 \cdot 185}{-}$ & $\begin{array}{l}2 \cdot 85 \\
3 \cdot 33\end{array}$ & $\begin{array}{l}1.91 \\
1.00\end{array}$ \\
\hline $\begin{array}{l}19 \text { April-15 June } 1966 \\
16 \text { June-20 July } 1966\end{array}$ & $\begin{array}{r}4 \\
19\end{array}$ & $\begin{array}{l}76 \\
71\end{array}$ & $\begin{array}{r}10 \\
2\end{array}$ & $\begin{array}{l}36 \\
17\end{array}$ & $\begin{array}{r}5 \cdot 3 \\
26 \cdot 8\end{array}$ & $\begin{array}{l}27 \cdot 8 \\
11 \cdot 8\end{array}$ & $\begin{array}{l}9 \cdot 357 \\
0.973\end{array}$ & $\begin{array}{l}2 \cdot 00 \\
2 \cdot 74\end{array}$ & $\begin{array}{l}2 \cdot 50 \\
6 \cdot 50\end{array}$ \\
\hline
\end{tabular}

$r e l$ is the number of marks released, or retrapped and released, in the period covered by the dates, starting on the first day minus one, and omitting the last day. An insect captured twice will carry two marks and hence be counted as two releases.

$\mathrm{rec}$ is the number of marks recaptured in the period covered by the dates of marks put on during that period.

Days survived is equivalent to expectation of life, but since the figures are based on marks, they differ slightly from $E_{2}$ in table 7 , which are based on individuals.

Since there is a very close agreement between $E_{1}$ and $E_{2}$, one might expect to get evidence of the different survival rates of white and orange insects by comparing the percentages of orange and white insects recaptured out of the total numbers released, as in table 8 . In both seasons a higher percentage of white insects were recaptured than of orange, but the figures are not significant. However, taking the first part of each season separately, we find that in both years the whites show a significantly higher percentage of recaptures than the orange insects (for 1965, $\mathrm{P}<0.05$; for 1966, $\mathrm{P}<0.01$ ), whilst later on there is no significant difference between the two. This could be interpreted as suggesting that the white insects are surviving better during the first part of the season than the orange, but, at least in 1965, this conflicts with evidence based on survival rate and expectation of life (tables 6 and 7). However, the figures in table 8 can be explained by a 
behavioural difference between the two morphs. Subjective observations suggest that the white insects are less active and weaker flyers than the orange, hence a higher proportion of the available whites than the oranges are caught because they are easier to catch and because they tend to remain for longer in the area of study. One would also expect more multiple recaptures of white than of orange insects if this is the correct explanation, but the figures are too small for a significant difference to be detected (for both years combined, 3 out of 20 white recaptures were recaptured more than once, compared with only 4 out of 43 orange recaptures).

Table 8 also shows that the days survived by white recaptures is low in 1965 and high in 1966, which agrees with survival rate estimates given in table 6. In both years there is a seasonal increase in the percentage of orange insects recaptured (which explains why the percentage of white recaptures is significantly higher than the orange during the first part of

TABLE 9

H. misippus: marks recaptured as a percentage of marks released for misippus and inaria

Date

21 May-7 July 1965

19 April-20 July 1966

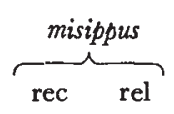

$28 \quad 187$

$30 \quad 162$

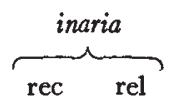

$11 \quad 41$

$5 \quad 38$

\begin{tabular}{|c|c|}
\hline \multicolumn{2}{|c|}{ Percentage } \\
\hline misippus & inaria \\
\hline $15 \cdot 0$ & $26 \cdot 8$ \\
\hline $18 \cdot 5$ & $13 \cdot 2$ \\
\hline
\end{tabular}

$\chi \stackrel{2}{(1)}$

$2 \cdot 550$

$0 \cdot 298$

\section{$\mathbf{P}$} $<0.2,>0.1$ $<0.9,>0.8$

For explanation of $r e c$ and rel, see table 8.

the season, but not later on). For 1965 the figures are 11.0 per cent. increasing to 20.7 per cent., but this is not significant $\left(\chi\left(\begin{array}{l}2 \\ )\end{array}=2 \cdot 244\right.\right.$, $0 \cdot 2>\mathrm{P}>0 \cdot 1$ ). For 1966 the increase is from $5 \cdot 3$ to $26 \cdot 8$ per cent., and this is highly significant $(\chi(1)=11 \cdot 276, \mathrm{P}<0 \cdot 001)$. The corresponding figures for white insects are based on very small samples, but they do not show the same change. From table 6 it was tentatively concluded that survival of all females improved during the course of the season. The seasonal change in the percentage of orange recaptures supports this conclusion. This seasonal improvement in the survival rate of orange insects cannot be related to mimicry because the orange forms bear a poor resemblance to the model, and because the model was declining in numbers (relative to the mimic) rather than increasing (see table 11).

Table 9 compares the proportion of marks recaptured out of the total number of marks released for misippus and inaria. There is no significant difference between the proportions of misippus recaptured and those of inaria.

It is possible to check the survival rates calculated above by another independent method. If two morphs have different mortalities, then the frequencies of the two morphs should differ in freshly emerged and in old insects. Both in 1965 and 1966 there were no significant differences in the proportion of whites amongst old and fresh insects, suggesting that the two had similar survival rates. This agrees with the survival rates shown in table 6 for 1966 but not for 1965 . However, since the number of fresh white insects caught in 1965 was very small (6), the apparent discrepancy between the two methods is not significant. Similarly there were no significant 
differences in the proportion of inaria amongst old and fresh insects in the two years. Hence there is no evidence here for a difference in survival rate between misippus and inaria, but the numbers in the rarer classes were again small.

Table 10 shows the percentage of fresh insects caught during different parts of the seasons. Taking the most favourable periods, there was a significant decline in the percentage of fresh insects during the 1965 season, suggesting that survival was better in the second part of the season than in the first. This confirms the conclusions based on survival rate and on the percentage recaptures of orange insects (tables 6 and 8). In 1966 the percentage of fresh insects was low in April and May, and then, as in 1965, high in June but low in July. This suggests that survival was high early in

TABLE 10

Percentage of fresh insects out of total Hypolimnas misippus caught in 1965 and 1966

\begin{tabular}{|c|c|c|c|c|c|}
\hline Date & Fresh & Old & $\begin{array}{l}\text { Percentage } \\
\text { fresh }\end{array}$ & $x_{(1)}^{2}$ & $\mathbf{P}$ \\
\hline $\begin{array}{l}2 \text { June-16 June } 1965 \\
17 \text { June-7 July } 1965\end{array}$ & $\begin{array}{l}28 \\
17\end{array}$ & $\begin{array}{l}45 \\
74\end{array}$ & $\left.\begin{array}{l}38 \cdot 4 \\
18 \cdot 7\end{array}\right\}$ & 6.981 & $<0.01$ \\
\hline $\begin{array}{l}19 \text { April-17 May } 1966 \\
18 \text { May-27 June } 1966 \\
\text { 82 June-20 July } 1966\end{array}$ & $\begin{array}{r}7 \\
22 \\
7\end{array}$ & $\begin{array}{l}50 \\
57 \\
40\end{array}$ & $\left.\begin{array}{l}12.3 \\
27 \cdot 8 \\
14.9\end{array}\right\}$ & $\begin{array}{l}3 \cdot 900 \\
2 \cdot 108\end{array}$ & $\begin{array}{c}<0.05 \\
<0.2,>0 \cdot 1\end{array}$ \\
\hline $\begin{array}{l}2 \text { June-7 July } 1965 \\
18 \text { May-20 July } 1966\end{array}$ & $\begin{array}{l}45 \\
29\end{array}$ & $\begin{array}{r}110 \\
93\end{array}$ & $\left.\begin{array}{l}29 \cdot 0 \\
23 \cdot 8\end{array}\right\}$ & 0.715 & $<0.5,>0.3$ \\
\hline
\end{tabular}

the season, poor in June, and then rose again in July. (Comparison with survival rate estimates is not possible here because there were too few recaptures in the early part of the season for the figures to be meaningful.) Table 10 also compares the percentage of fresh insects caught in 1965 with those caught in the comparable period of 1966. There is no significant difference between the figures, so there is no evidence of a different pattern of survival in the two seasons.

\section{Changes in MORPh FReQUency IN 1965 AND 1966}

Edmunds (1966) showed that between May and July 1965, of the total number of models and mimics caught, the percentage of models decreased significantly from 30.6 to zero. At the same time the percentage of female Hypolimnas caught with white on the hind wings decreased from 44.4 to 12.5 . This correlation between the population of the model and the ratio of the morphs of its mimic can be explained by the whites (which resemble the model more closely than do the orange) being at a selective advantage to orange when the model was present, but at a disadvantage when it was absent. Stride (1956) has shown that male Hypolimnas court orange females more actively than they court females with white on the hind wings; hence there will be two opposing selective forces acting on the insects, one favouring white on the hind wings, the other favouring orange. The situation is actually more complex than this since presence of white on the hind wings frequently modifies the colour of the fore wings (table 4). Presumably if the fore wings depart too much from the black and white of typical misippus, 
then the insect will no longer derive protection from its resemblance to Danaus chrysippus, which always has black and white tipped fore wings in Ghana.

\section{TABLE 11}

Numbers of Danaus chrysippus and female Hypolimnas misippus captured at Legon in 1965 and 1966

\begin{tabular}{cccc} 
Date & D. chrysippus & H. misippus & $\begin{array}{c}\text { Percentage } \\
\text { D. chrysippus }\end{array}$ \\
1965 14 May-27 May & 34 & 77 & $30 \cdot 6$ \\
28 May-10 June & 9 & 61 & $12 \cdot 9$ \\
11 June-24 June & 4 & 62 & $6 \cdot 1$ \\
25 June-7 July & 0 & 56 & $0 \cdot 0$ \\
& \multicolumn{4}{c}{$\chi_{(3)}^{2}=34.56, P<0.001$} \\
1966 & 46 & 43 & $51 \cdot 7$ \\
18 April-1 May & 65 & 8 & $89 \cdot 0$ \\
2 May-15 May & 56 & 26 & $68 \cdot 3$ \\
16 May-29 May & 23 & 10 & $67 \cdot 6$ \\
30 May-12 June & 25 & 27 & $48 \cdot 1$ \\
13 June-26 June & 11 & 19 & $36 \cdot 7$ \\
27 June-10 July & 5 & 14 & $26 \cdot 3$ \\
11 July-22 July & $\chi_{(8)}^{2}=51 \cdot 01, P<0.001$ &
\end{tabular}

Note.-The $\chi^{2}$ figure for the 1965 results is derived from $\Sigma\left((o-e)^{2} / e\right)$, whilst that given in Edmunds (1966) is derived from $\left(\Sigma\left(o^{2} / e\right)\right)-n$.

\section{TABLE 12}

Numbers of female Hypolimnas misippus captured in 1965 and 1966 with white on the hind wings

\begin{tabular}{|c|c|c|c|c|}
\hline & & & & \\
\hline & Date & Orange & White & white \\
\hline 1965 & $\begin{array}{l}14 \text { May-27 May } \\
28 \text { May-10 June } \\
11 \text { June-24 June } \\
25 \text { June-7 July }\end{array}$ & $\begin{array}{l}35 \\
46 \\
51 \\
49\end{array}$ & $\begin{array}{r}28 \\
15 \\
11 \\
7\end{array}$ & $\begin{array}{l}44 \cdot 4 \\
24 \cdot 6 \\
17 \cdot 8 \\
12 \cdot 5\end{array}$ \\
\hline \multicolumn{5}{|c|}{$\chi_{(3)}^{2}=18.939, P<0.001$} \\
\hline 1966 & $\begin{array}{l}18 \text { April-1 May } \\
2 \text { May-15 May } \\
16 \text { May-29 May } \\
30 \text { May-12 June } \\
13 \text { June-26 June } \\
27 \text { June-10 July } \\
11 \text { July-22 July }\end{array}$ & $\left.\begin{array}{r}29 \\
4 \\
28 \\
7 \\
29 \\
29 \\
23 \\
17\end{array}\right\} 3$ & $\left.\begin{array}{r}16 \\
5 \\
6 \\
3 \\
7 \\
7 \\
4\end{array}\right\}$ & $\begin{array}{l}\left.\begin{array}{l}35 \cdot 6 \\
55 \cdot 6 \\
17 \cdot 6\end{array}\right\} 38 \cdot 9 \\
30 \cdot 0 \\
19 \cdot 4 \\
23 \cdot 0 \\
19 \cdot 0\end{array}$ \\
\hline \multicolumn{5}{|c|}{$x_{(4)}^{2}=6.646,0.2>P>0.1$} \\
\hline
\end{tabular}

Notes.-1.* Figures for each fortnight may include insects first captured earlier, but they do not include retraps in the same fortnight. Hence when two fortnights are added together, an insect caught in both periods can only be counted once.

2. The total numbers of Hypolimnas in each fortnight given in table 12 may differ from those given in table 11 . This is either because records of white and orange insects were not initiated until after collection had started (e.g. 14th May to 27th May 1965); or because some Hypolimnas were caught in 1966 in addition to those captured at random together with Danaus.

In 1966, the situation was quite different from that in 1965. Table 11 gives the numbers of Danaus and of female Hypolimnas captured during fortnightly periods in 1965 and 1966. In both seasons there was a significant 
decline in the proportion of models caught, but whilst Danaus was rarer than Hypolimnas throughout 1965 and completely disappeared towards the end of June, in 1966 it was the commoner species for most of the season and never completely disappeared. It is possible that it declined to zero after observations ceased on 22nd July, but by the middle of August some Danaus were caught at Legon.

TABLE 13

Numbers of white and orange female Hypolimnas misippus captured in 1966

$\left.\begin{array}{cccccc}\text { Date } & \text { Orange } & \text { White } & \begin{array}{c}\text { Percentage } \\ \text { white }\end{array} & \chi_{(1)}^{2} & \text { P } \\ \text { 18 April-13 May } & 32 & 21 & 39.6 \\ \text { 14 May-22 July } & 101 & 25 & 19.7\end{array}\right\} 6.753<0.01$

Table 12 gives the numbers of white and orange female Hypolimnas caught during fortnightly periods in 1965 and 1966. In 1965 there was a significant decline in the proportion of white forms during the course of the season. In 1966, even when the smaller totals (when Hypolimnas was scarce) are added to the larger ones, no significant change in the frequency of the morphs can be detected: the data show no evidence of heterogeneity. But, if the most favourable period is selected, as in table 13, there is evidence that the percentage of white mimics again fell during the course of the season. However, it is clear from tables 11, 12 and 13 that in 1966 the decline in the percentage of whites occurred early, at a time when the model was still more abundant than Hypolimnas. Table 14 gives the regression coefficients,

TABLE 14

Regression coefficients ( $\mathrm{X}$ and $\mathrm{Y}$ ) of abundance of model and percentage of mimics with white on hind wings

\begin{tabular}{lrcccc}
\multicolumn{1}{c}{ Date } & \multicolumn{1}{c}{$\boldsymbol{X}$} & $\boldsymbol{X}$ & $\begin{array}{c}\text { Standard } \\
\text { deviation }\end{array}$ & $\begin{array}{l}\text { Correlation } \\
\text { coefficient }\end{array}$ & $\mathbf{P}$ \\
1965 fortnightly & 11.756 & 1.055 & 0.589 & 0.9988 & $<0.01$ \\
1965 weekly & 13.595 & 0.864 & 4.694 & 0.927 & $<0.01$ \\
1966 fortnightly & 4.054 & 0.444 & 9.04 & 0.695 & $>0.05$
\end{tabular}

standard deviations and correlation coefficients for the data presented in tables 11 and 12. If the 1965 totals are taken each week instead of each fortnight, the figures obtained are very much the same. It is clear that in 1965 there is a strong correlation between model abundance and morph frequency, but in 1966 there is no evidence of such a correlation.

It has been shown in section 5 that the survival rate of the orange insects increased during the 1966 season, but there is no evidence for a seasonal change in the survival rate of the whites. This seasonal increase in survival rate of the orange insects explains the decline in the relative frequency of the whites in 1966, and could account for at least part of the decline in 1965. This could mean that there is no mimetic association between Hypolimnas misippus and Danaus chrysippus in Ghana, as was originally concluded by Stride (1956) although later rescinded (Stride, 1957). However, it has been shown that the white insects had a very low survival rate in 1965 which it is reasonable to correlate with the scarcity of models in that year, since in 
1966 models were abundant and survival rate was high. Thus there is evidence for two factors affecting the survival rate of white relative to orange: one is the abundance of the model; the other is an unidentified factor which causes the survival rate of orange to increase between April

TABLE 15

Numbers of female Hypolimnas misippus captured in 1965 and 1966 with fore wing of misippus and inaria patterns

\begin{tabular}{|c|c|c|c|c|}
\hline \multicolumn{2}{|r|}{ Date } & misippus & inaria & $\begin{array}{l}\text { Percentage } \\
\text { inaria }\end{array}$ \\
\hline 1965 & $\begin{array}{l}14 \text { May-27 May } \\
28 \text { May-10 June } \\
11 \text { June-24 June } \\
25 \text { June-7 July }\end{array}$ & $\begin{array}{l}29 \\
55 \\
46 \\
47\end{array}$ & $\begin{array}{r}6 \\
6 \\
16 \\
9\end{array}$ & $\begin{array}{r}17 \cdot 1 \\
9 \cdot 9 \\
25 \cdot 8 \\
16 \cdot 1\end{array}$ \\
\hline \multicolumn{5}{|c|}{$\chi_{(3)}^{2}=5.178,0.2>P>0.1$} \\
\hline 1966 & $\begin{array}{l}18 \text { April-15 May } \\
16 \text { May-12 June } \\
13 \text { June-26 June } \\
27 \text { June-10 July } \\
11 \text { July-22 July }\end{array}$ & $\begin{array}{l}47 \\
35 \\
30 \\
22 \\
13\end{array}$ & $\begin{array}{l}7 \\
8 \\
6 \\
8 \\
8\end{array}$ & $\begin{array}{l}13 \cdot 0 \\
18 \cdot 6 \\
16 \cdot 7 \\
26 \cdot 7 \\
38 \cdot 1\end{array}$ \\
\hline \multicolumn{5}{|c|}{$\chi_{(4)}^{2}=7.200,0.2>P>0.1$} \\
\hline $\begin{array}{l}1965 \\
1966\end{array}$ & $\begin{array}{l}14 \text { May-7 July } \\
18 \text { April-22 July }\end{array}$ & $\begin{array}{l}173 \\
143\end{array}$ & $\begin{array}{l}35 \\
36\end{array}$ & $\begin{array}{l}16 \cdot 8 \\
20 \cdot 2\end{array}$ \\
\hline
\end{tabular}

and July. This factor is not related to the abundance of the model, and only affects the orange insects which do not bear a close resemblance to Danaus. Hence it does not appear to be related to mimicry.

Table 15 gives the numbers of Hypolimnas misippus caught in 1965 and 1966 with fore wings of misippus and inaria patterns. There is no significant change in the proportions of the two morphs during either of the seasons,

TABLE 16

Numbers of female Hypolimnas misippus captured in 1965 and 1966 with fore wing of misippus and inaria patterns

\begin{tabular}{|c|c|c|c|c|c|}
\hline Date & misippus & inaria & $\begin{array}{l}\text { Percentage } \\
\text { inaria }\end{array}$ & $\chi_{(1)}^{2}$ & $\mathbf{P}$ \\
\hline $\begin{array}{l}1965 \text { 14 May-10 June } \\
\text { 11 June-7 July }\end{array}$ & $\begin{array}{l}83 \\
90\end{array}$ & $\begin{array}{l}11 \\
24\end{array}$ & $\begin{array}{l}11 \cdot 7 \\
21 \cdot 0\end{array}$ & 2.585 & $<0.2,>0 \cdot 1$ \\
\hline $\begin{array}{l}1966 \text { 18 April-14 June } \\
15 \text { June-22 July }\end{array}$ & $\begin{array}{l}88 \\
55\end{array}$ & $\begin{array}{l}15 \\
21\end{array}$ & $\begin{array}{l}14 \cdot 6 \\
27 \cdot 6\end{array}$ & $3 \cdot 871$ & $<0.05$ \\
\hline
\end{tabular}

nor are the 1966 figures significantly different from those of 1965. However, the 1966 figures do suggest a gradual increase in the proportion of inaria during the course of the season, and if the most favourable dates are selected (as in table 16), a significant change can be detected. A similar change may have occurred in 1965 although the figures are not significant. If the figures for the two years are added, $\chi\left({ }_{1}^{2}\right)=6.417, \mathrm{P}<0.02$. Since this increase in the frequency of inaria occurred in both years, and since there is no significant difference in frequency between the two years, it appears to 
be unrelated to the frequency of the model. It does, however, suggest that there is an increase in the survival rate of inaria relative to misippus during the course of the season. This supports the tentative conclusions based on survival rate estimates that the survival of female Hypolimnas improves as the season advances, and that inaria has a slightly higher survival rate than misippus. Selective values calculated from survival rate estimates show that misippus was at a disadvantage of 54 per cent. relative to inaria in 1965, and of 50 per cent. in 1966.

\section{THE COURTSHIP BEHAVIOUR OF HYPOLIMNAS MISIPPUS}

Stride $(1956,1957)$ has shown that male $H$. misippus court artificial models with orange hind wings more actively than they court models with white on the hind wings. He provides evidence to suggest that white on the

TABLE 17

Proportions of the different morphs of female Hypolimnas misippus observed giving the ascending flight response to a courting male

\begin{tabular}{|c|c|c|c|c|}
\hline & \multicolumn{2}{|c|}{ Hind wing } & \multicolumn{2}{|c|}{ Fore wing } \\
\hline & Orange & White & misippus & inaria \\
\hline $\begin{array}{l}\text { Number of females giving ascending flight } \\
\text { response }\end{array}$ & 22 & 21 & 35 & 8 \\
\hline $\begin{array}{l}\text { Number of females not giving ascending } \\
\text { flight response }\end{array}$ & 110 & 67 & 153 & 24 \\
\hline $\begin{array}{l}\text { Percentage of females giving ascending } \\
\text { flight response }\end{array}$ & $16 \cdot 7$ & $23 \cdot 9$ & $18 \cdot 6$ & $25 \cdot 0$ \\
\hline$\chi_{(1)}^{2}$ & $<0$ & $\begin{array}{l}2 \\
>0 \cdot 2\end{array}$ & $<0$ & 0.5 \\
\hline
\end{tabular}

hind wings inhibits courtship, and that this is the reason why a white hind-winged form of Hypolimnas has not become the commonest morph in West Africa where the model always has white hind wings. Stride's conclusions were based on experiments with free-living males and dead and artificial test insects, but not free-living females. A characteristic feature of the courtship behaviour of Hypolimnas misippus is the female's " ascending flight" response to the male (Stride, 1956, 1958). Stride has shown that this is a means whereby a fertilised female can escape the persistent attentions of a courting male since she only breaks off the ascending flight when the male has given up the pursuit and returned to the ground. I can confirm that not one of many ascending flights observed at Legon was followed by copulation. If males court and copulate less frequently with white than with orange females, then one would expect proportionately more of the white ones to be virgin and receptive, whilst proportionately more of the orange would be unreceptive and hence liable to give the ascending flight response. Table 17 gives the numbers of ascending flight responses of orange and white females observed at Legon in 1968 compared with the numbers of the two morphs seen on the same days which were not giving the ascending flight response. There was actually a slightly higher percentage of ascending flights observed in white than in orange females, although the difference is not significant. Thus although white on the hind wings may to some extent inhibit courtship in males, there is no evidence 
that it results in proportionately fewer white females being fertilized than orange. Hence there is no evidence for the orange females being at a sexual advantage to the white ones.

\section{Populations of hypolimnas misippus at other times OF THE YEAR}

The populations of Hypolimnas misippus and Danaus chrysippus have been studied intensively for only two or three months of the year during the main rainy season. At other seasons, Hypolimnas is usually very scarce, although it may become comparatively abundant for a few days after rain, particularly in October and November. Despite insufficient numbers of insects, the figures available show that some changes were occurring in the

TABLE 18

Model-mimic ratios at Legon and elsewhere in Ghana

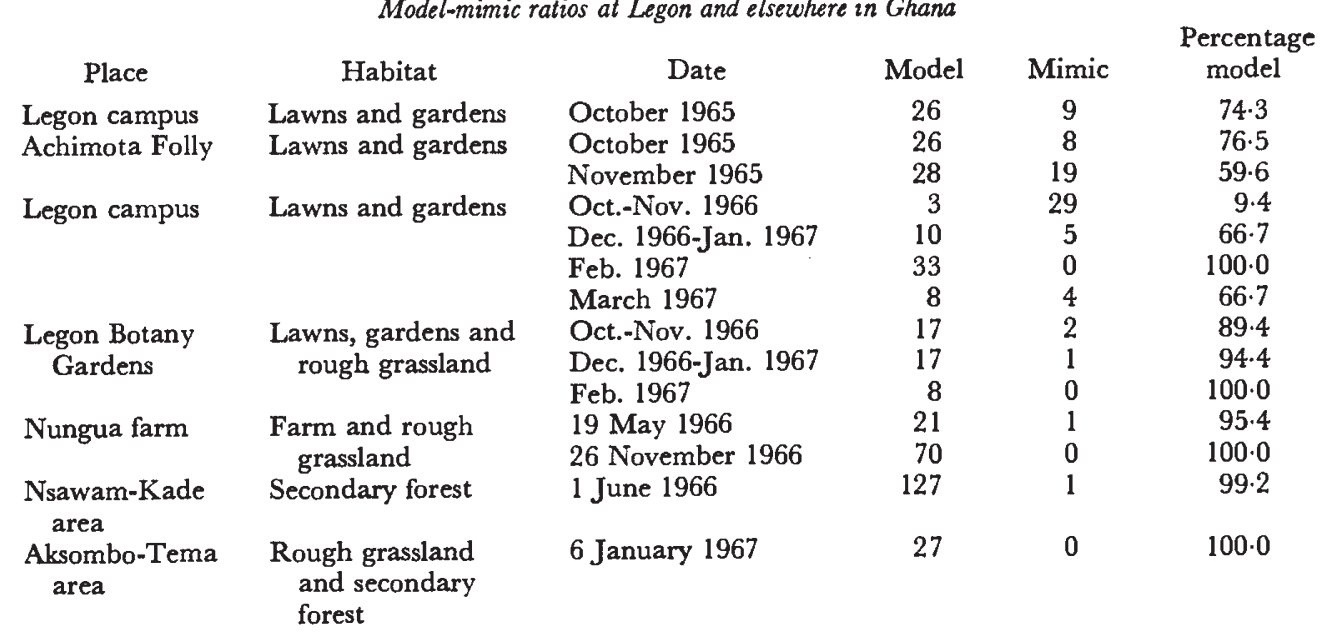

model-mimic ratios and in morph frequency throughout the year. Table 18 gives the model-mimic ratios during the dry season. The 1965 figures are based on captures, the 1966-67 ones on insects observed and identified in the field. Two conclusions can be drawn from these figures. Firstly, in all of the areas which consist mainly of farms, rough grassland or secondary forest, Danaus is far more abundant than Hypolimnas. Secondly, in the two areas consisting of lawns and gardens with very little rough grassland (Legon campus and Achimota Folly, which is about 5 miles from Legon), the model was usually more abundant than the mimic, but the situation was quite different in October and November 1965 compared with the same period in 1966. The difference between Legon campus and Legon Botany Gardens (which abut on to one another) in October and November 1966 is very striking.

Table 19 gives the proportions of the various morphs of Hypolimnas misippus captured at Legon and Achimota in 1965 and seen at Legon in 1966-67. The numbers are too small for any significance to be attached to them, but it appears that in October and November 1965 the model was abundant yet few mimics had white on the hind wings, whilst in 1966 the model was scarce and rather more mimics had white on the hind wings. 
This supports the view that some factor other than model abundance is affecting the frequency of the orange and white morphs.

\section{HYPOLIMNAS MISIPPUS IN OTHER PARTS OF AFRIGA}

The present work shows that whilst there is evidence that the white morphs have a lower survival rate than the orange in the absence of the

TABLE 19

Hypolimnas misippus: morph frequencies in 1965 and in 1966-67

\begin{tabular}{lcccccc}
\multicolumn{1}{c}{ Date } & misippus & inaria & $\begin{array}{c}\text { Percentage } \\
\text { inaria }\end{array}$ & Orange & White & $\begin{array}{c}\text { Percentage } \\
\text { white }\end{array}$ \\
Oct.-Nov. 1965 & 26 & 10 & $27 \cdot 8$ & 31 & 5 & $13 \cdot 9$ \\
Oct.-Nov. 1966 & 20 & 6 & $23 \cdot 1$ & 17 & 9 & $34 \cdot 6$ \\
Dec. 1966-March 1967 & 4 & 2 & $33 \cdot 3$ & 5 & 1 & 16.7
\end{tabular}

model, the situation is actually very complex. Further evidence for the effectiveness of the mimicry should be obtainable from data in East Africa where the model rarely has white present on the hind wings (Owen and Chanter, 1968). At Dar es Salaam, Tanzania, between 29th April and 5th June 1967, I collected 90 Danaus chrysippus and 18 female Hypolimnas misippus on the campus of the University College. The Danaus is dimorphic

TABLE 20

Numbers of different morphs of Danaus chrysippus and Hypolimnas misippus caught and seen at Dar es Salaam

\begin{tabular}{|c|c|c|c|c|c|c|}
\hline Species & $\begin{array}{l}\text { chrysippus } \\
\text { or misippus }\end{array}$ & $\begin{array}{l}\text { dorippus } \\
\text { or inaria }\end{array}$ & $\begin{array}{c}\text { Percentage } \\
\text { dorippus } \\
\text { or inaria }\end{array}$ & Orange & White & $\begin{array}{c}\text { Percentage } \\
\text { white }\end{array}$ \\
\hline $\begin{array}{c}\text { Danaus caught } \\
\text { seen }\end{array}$ & $\begin{array}{l}20 \\
24\end{array}$ & $\begin{array}{l}70 \\
89\end{array}$ & $\begin{array}{l}77 \cdot 8 \\
78 \cdot 8\end{array}$ & $\begin{array}{r}88 \\
111\end{array}$ & $\begin{array}{l}2 \\
2\end{array}$ & $\begin{array}{l}2 \cdot 2 \\
1 \cdot 8\end{array}$ \\
\hline $\begin{array}{c}\text { Hypolimnas caught } \\
\text { seen }\end{array}$ & $\begin{array}{l}12 \\
19\end{array}$ & $\begin{array}{r}6 \\
10\end{array}$ & $\begin{array}{l}33 \cdot 3 \\
37 \cdot 9\end{array}$ & $\begin{array}{l}17 \\
28\end{array}$ & $\begin{array}{l}1 \\
1\end{array}$ & $\begin{array}{l}5 \cdot 5 \\
3 \cdot 5\end{array}$ \\
\hline
\end{tabular}

Note.-The two Danaus with white on the hind wing were both loo. The single Hypolimnas with white on the hind wing was 4op.

here comprising form dorippus (resembling form inaria of Hypolimnas) and the typical form chrysippus (resembling form misippus of Hypolimnas). Only two specimens of the model had any trace of white on the hind wings. These were both of the dorippus form, and the white was barely noticeable (score loo on my Hypolimnas scoring method). Table 20 gives the numbers of the various morphs of model and mimic caught at Dar es Salaam, and also the numbers seen and identified (whether caught or not). Too few Hypolimnas were caught for comparison with figures at Legon to show any significant differences, but table 21 compares the numbers seen at Dar es Salaam with those caught at Legon in 1966. There were significantly fewer Hypolimnas with white on the hind wing at Dar es Salaam than at Legon. As the model has virtually no white on the hind wing at Dar es Salaam, this supports the view that white on the hind wings of Hypolimnas in Ghana is an adaptation giving protection to the mimic by improving its resemblance to the model. 
But it also confirms that white has some other advantage to Hypolimnas, otherwise forms with white on the hind wings would be totally absent at Dar es Salaam.

At Dar es Salaam the commoner form of Danaus is dorippus which is absent from Ghana. Table 22 shows that the percentage of the inaria form of Hypolimnas seen at Dar es Salaam is significantly greater than that at Legon. This supports the hypothesis that the resemblance of inaria to dorippus is of advantage to the mimic, but as the percentage of inaria is still much lower than that of dorippus, some other factor must also be involved.

TABLE 21

Comparison of orange and white Hypolimnas misippus seen at Dar es Salaam with those caught at Legon in 1966

$\left.\begin{array}{ccc}\text { Place } & \text { Orange } & \text { White } \\ \text { Legon, 1966 } & 113 & 46 \\ \text { Dar es Salaam, 1967 } & 28 & 1\end{array}\right\} \begin{array}{ccc}\chi_{(1)}^{2} & P \\ 5.849 & <0.02\end{array}$

It is clearly desirable to get more information on the ratios of the morphs of these two species elsewhere in Africa, and also on the various selective pressures acting on these morphs.

TABLE 22

Comparison of frequency of inaria seen at Dar es Salaam with those caught at Legon in 1965

$\left.\begin{array}{lccc}\multicolumn{1}{c}{\text { Place }} & \text { misippus } & \text { inaria } & \begin{array}{c}\text { Percentage } \\ \text { inaria }\end{array} \\ \text { Legon, 1965 } & 173 & 35 & 16.8 \\ \text { Dar es Salaam, } 1967 & 19 & 10 & 37.9\end{array}\right\} 4.074<0.05$

\section{Discussion}

The polymorphism of Cepaea nemoralis (L.) is characterised by stability of the frequencies of the various morphs over long periods of time (Goodhart, 1956, 1958; Cain and Currey, 1963), despite the occurrence of selective predation on the different morphs (Sheppard, 1951). Maniola jurtina (L.) also has stable morph frequencies over most of the British Isles, but in the extreme south-west ecological conditions evidently favour a different morph frequency from elsewhere (Ford, 1964). Here the morph frequency changed very considerably at one place during the course of four years. In Panaxia dominula (L.), marked changes in gene frequency have also been observed, but there is usually considerable stability from year to year (Ford, 1964). Even in the case of melanic moths where dramatic changes in morph frequency have occurred during the last century (Kettlewell, 1958), the changes from year to year have probably been comparatively small. The best known example of selection changing morph frequencies during a period of a few months is that of chromosome types $S T$ and $C H$ in Drosophila pseudoobscura in southern California (Dobzhansky, 1951). The change in the frequency of the white and orange forms of Hypolimnas misippus in 1965 are of a similar nature to those found in Drosophila, but they differ in that 
they involve a character visible in the living animal. I have given evidence suggesting that this change is due partly to the survival rate of the white morph being affected by the relative abundance of the model, and partly by the survival rate of the orange morph being affected by some unidentified factor. It is reasonable, then, to attempt to explain at least some of the changes in morph frequency in terms of the abundance of the model and the degree of resemblance of the various morphs to the model.

It has long been known that mimics must not be too common relative to the model, but it is only recently that this has been demonstrated experimentally by introducing artificial mimetic and non-mimetic morphs into a natural population (Brower, Cook and Croze, 1967). It was found that the mimic was only at a selective advantage to the non-mimetic form when it was not too abundant relative to the model. Presumably, when it is too common, predators develop a searching image for the mimic instead of learning to avoid the model. However, if the model is very distasteful, the mimic may still receive some protection from its resemblance even when it outnumbers the model by nine to one (Brower, 1960). Schmidt (1958) has shown that a mimic can derive some protection even if its resemblance to the model is very imperfect. Duncan and Sheppard (1965) have recently shown that when the model is highly distasteful, there is little selective advantage in improving the mimicry beyond a certain point; but when the model is only moderately unpleasant, selection will continue to operate to produce a very close resemblance between mimic and model. In the case of Hypolimnas misippus in Ghana, the model is usually more abundant than the mimic. Form inaria shows practically no resemblance to the model, and there is no evidence that it derives any protection from a resemblance to Danaus. Form misippus in Ghana resembles the model in the colour of its fore wing (though not of its hind wing), but again there is no evidence that it derives any protection from this similarity. Consequently one can regard inaria as non-mimetic and misippus as probably non-mimetic in Ghana. This conclusion is based on fore wing colouration only. On the hind wing, there is strong evidence that white gives considerable protective value because of its resemblance to the model, but there is no evidence that orange is of any protective value.

A tentative picture of the selection pressures acting on hind wing colouration of Hypolimnas misippus in Ghana can now be suggested. Insects with white on the hind wings are at a selective disadvantage to insects with entirely orange hind wings because with apparently reduced powers of flight, they will be more likely to be caught by predators. Stride's evidence that white insects are at a sexual disadvantage compared to orange ones is not supported by field observations. White Hypolimnas will be at a selective advantage to orange when Danaus is common, but at a disadvantage when Danaus is rare. There is also an unidentified factor causing an increase in the survival rate of orange insects between April and July. It is presumably the variation in intensity of these last two factors during the course of the year that determines the frequencies of the morphs and prevents the elimination of either form.

Since the species is rare for four or five months throughout the dry season and has a generation time of about six weeks (reared in the laboratory on its natural food plant at Legon, Portulaca quadrifida L.), it is possible that the sudden increase in numbers when the rains come is something in the 
nature of a "Founder" effect (Mayr, 1954). Assuming there is no dry season diapause, a very small number of females in the dry season presumably produce a large population at the beginning of the rains. The genotypes of these founding females is likely to be determined by selection in the dry season. Despite the small numbers, there is no evidence of chance (drift) being important. If it were, then one would expect variation in the frequency of white in April and May in different years. But the morph frequencies were similar at the beginning of the season in 1965, 1966 and also in 1968 (39.7 per cent. white females between 23rd April and 31st May 1968 declining to 26.7 per cent. in June, based on insects seen and hence including multiple sightings. $\mathrm{N}=239$ for April and May, $\mathrm{N}=86$ for June.) Similarly in all three years the percentage of inaria was low at the beginning of the season (14.2 per cent. in April and May 1968). This suggests that the genotypes of the females emerging early in the rainy season may not be those best adapted to this environment. Selection will then eliminate a higher proportion of the white and of the misippus females than of the orange or the inaria, so that after one or two generations the proportions of the various morphs are stabilised. So the evidence suggests that selection favours different morph ratios at different times of the year, and that drift is not important.

Differential mortality on the two morphs at an immature stage of the life history could also explain some of the observed changes in morph frequency, but there is no experimental evidence to support this at present.

Poulton (1908) believed that Hypolimnas misippus was a Müllerian mimic, but this is not accepted by more recent workers (Carpenter and Ford, 1933; Stride, 1956). Punnett (1915) gives extensive evidence of various birds and mammals rejecting Danaus chrysippus, but occasionally a lizard or a bird (such as Lanius cristatus) is found which eats it readily. Evidently Danaus is not distasteful to all predators, and conversely one might expect to find that some predators find Hypolimnas distasteful although most will eat it readily. The distinction between Batesian and Müllerian mimicry is not always clear-cut. In Ghana, I know of no observation of Danaus being eaten in the wild, but I have two records of Hypolimnas being eaten. Dr L. R. Cole (personal communication) has seen a bee-eater (Aërops albicollis (Vieillot)) hawk at a courting pair of Hypolimnas and snap up the female; and I have seen a female lizard (Agama agama (L.)) eat an 0blw Hypolimnas. Also I have caught one male Hypolimnas with two beak marks on it. Lizards and cattle egrets (Bubulcus ibis (L.)) (which I have seen catch pierids) may be regular predators at Legon, but bee-eaters are only present in the dry season. The evidence as far as the hind wing is concerned thus indicates that some individuals of Hypolimnas misippus are Batesian mimics of Danaus chrysippus.

If Danaus chrysippus were distasteful to all of its likely predators, it is difficult to see why it should be polymorphic in East Africa: one would expect selection to favour the development of a single colour pattern so that predators could easily and quickly learn to avoid the whole population. However, the polymorphism can be explained by apostasis. Clark (1962) uses the term apostatic polymorphism to refer to polymorphisms which are maintained by predators which develop a searching image for the commoner of the morphs present, but not for the rarer morphs. He argues that apostatic polymorphism will not evolve in abundant species which are 
heavily predated since predators might then form a searching image for the rare morphs as well as the common ones. The most favourable conditions for the development of apostatic polymorphism will be those in which the species is either uncommon or slightly distasteful. In these cases the predator may develop a searching image only occasionally, either when other preferred foods are scarce, or when the species concerned is particularly abundant. It is probable that the polymorphism of Danaus chrysippus is apostatic, but it is not clear why this species should be monomorphic in West Africa.

Owen (1965b) finds that at low densities Limicolaria martensiana (Smith) is less polymorphic than at high densities, and he interprets this in terms of apostatic selection. At high densities the predators build up a searching image of the commonest form, so the rarer morphs are favoured by selection. At low densities the predators fail to build up a searching image and hence there is no advantage to be gained from being polymorphic.

In Hypolimnas misippus, there is no evidence that the colour of the fore wing is important in the mimetic association except in so far as an individual with white on the hind wings would be expected to have fore wings fairly similar to those of Danaus if it is to gain any protection from its resemblance. Apart from this, the two main fore wing categories appear to form the basis of a non-mimetic polymorphism in Ghana. There is at present no evidence that the polymorphism is maintained by apostatic selection since it shows the reverse of the density effect described by Owen for Limicolaria; the rarer morph inaria has a lower frequency when the population is high and a higher frequency later in the season when the population is low. There is evidence (though not conclusive) that inaria adults have a higher survival rate than misippus. This is partly balanced by a higher mortality of inaria in the immature stages (Ford, 1964, but again the evidence is not conclusive). However, since the frequency of inaria changes, one or both of these factors must vary in intensity during the course of the year.

\section{Summary}

1. A population of Danaus chrysippus and its Batesian mimic Hypolimnas misippus was studied during the rainy seasons of 1965 and 1966 in Ghana. Danaus is monomorphic in Ghana, all individuals having white hind wings. Hypolimnas females usually have orange hind wings, but some insects have white present in the orange. Presence of white on the hind wings is correlated with conditions on the fore wing intermediate between the typical black and white of misippus and the orange of form inaria.

2. In both years, the survival rate of all female Hypolimnas was about 65 per cent. per day (this figure does not allow for immigration and emigration).

3. In both years, the survival rate of orange Hypolimnas (i.e. with no white on the hind wing) was low in April and May but high in June and July. The reasons for this are not known, but they do not appear to be related to mimicry.

4. The survival rate of white Hypolimnas (i.e. with some white on the hind wing) was high in 1966 when the model was abundant, but low in 1965 when the model was scarce. Selective values calculated by two methods show white to have been at a disadvantage relative to orange of 63 per cent. and of 82 per cent. in 1965 . The white mimics are at a selective advantage 
compared to the orange when the model is present and abundant, but at a selective disadvantage when the model is rare or absent.

5. White Hypolimnas have a higher recapture rate than orange due to a behavioural difference between the two morphs.

6. There is no evidence that the orange Hypolimnas are at a sexual advantage compared to the white.

7. Calculations based on survival rate show that in both years the misippus form was at a selective disadvantage of about 50 per cent. compared to inaria. This, together with the probable higher mortality of immature inaria than of misippus, leads to the balanced polymorphism with respect to fore wing colouration.

8. There is no evidence that the morph frequencies are subject to change due to drift. Instead it is suggested that selection in the dry season results in a different morph frequency from that present in the rainy season.

9. Data from East Africa support the contention that the various morphs of Hypolimnas misippus derive protection from their resemblance to Danaus.

10. A method is described for using data on fresh and worn insects to give information on survival rates of different morphs.

11. It is suggested that the polymorphism of models such as Danaus chrysippus may be an apostatic polymorphism.

Acknowledgments.-I wish to thank Professor D. W. Ewer, Dr R. F. Ewer, Professor D. F. Owen, Dr L. M. Cook and my wife Janet for criticising the work and the manuscript at various stages of its completion; $\mathrm{Mr}$ W. Pople for help on some of the computing; and Professor I. Griffiths for making laboratory facilities available at the University College, Dar es Salaam.

\section{REFERENCES}

BROWER, J. VAN z. 1960. Experimental studies of mimicry. 4. The reactions of starlings to different proportions of models and mimics. Amer. nat., 94, $271-282$.

BROWER, L. P., COOK, L. M., AND GROZE, H. J. 1967. Predator responses to artificial Batesian mimics released in a neotropical environment. Evolution, 21, 11-23.

Cain, A. J., ANd currey, J. D. 1963. Area effects in Cepaea. Phil. Trans. R. Soc. Lond., ser. B, $246,1-81$.

CARPENTER, G. D. H., AND FORD, E. B. 1933. Mimicry. 134 pp. Methuen, London.

CLARKE, B. 1962. Balanced polymorphism and the diversity of sympatric species. In: Taxonomy and Geography, ed. D. Nichols, The Systematics Association publ. 4, 47-70.

COOK, L. M., BROWER, L. P., AND GROZE, H. J. 1967. The accuracy of a population estimation from multiple recapture data. 7. Anim. Ecol., 36, 57-60.

Dobzhansky, т. 1951. Genetics and the Origin of Species. 3rd edit., 364 pp. Columbia, New York.

DUNCAN, c. J., AND SHEPPARD, P. M. 1965. Sensory discrimination and its role in the evolution of Batesian mimicry. Behaviour, 24, 269-282.

EDMUNDs, M. 1966. Natural selection in the mimetic butterfly Hypolimnas misippus L. in Ghana. Nature, 212, 1478.

ELtringhaM, H. 1910. African mimetic butterfies. 136 pp. Clarendon, Oxford.

FISHER, R. A. 1958. Statistical methods,for research workers. 13th ed., $356 \mathrm{pp}$. Oliver and Boyd, London.

FISHER, R. A., AND FORD, E. B. 1947. The spread of a gene in natural conditions in a colony of the moth Panaxia dominula L. Heredity, 1, 143-174.

FORD, E. B. 1964. Ecological genetics. 335 pp. Methuen, London.

GOODHART, C. B. 1956. Genetic stability in populations of the polymorphic land snail, Cepaea nemoralis (L.). Proc. Linn. Soc. Lond., 167, 50-67.

GoODHART, c. B. 1958. Genetic stability in the snail Cepaea nemoralis (L.): a further example. Proc. Linn. Soc. Lond., 169, 163-167.

KETTLEWELL, H. B. D. 1958. A survey of the frequencies of Biston betularia (L.) (Lep.) and its melanic forms in Great Britain. Heredity, 12, 51-72. 
LEIGH, G. F. 1904. Synepigonic series of Papilio cenea (1902-3) and Hypolimnas misippus (1904), together with observations on the life history of the former. Trans. R. ent. Soc. Lond., 677-694.

LESLIE, P. H., AND CHITTY, D. 1951. The estimation of population parameters from data obtained by means of the capture-recapture method. I. The maximum likelihood equations for estimating the death-rate. Biometrika, 38, 269-292.

MAYR, E. 1954. Change of genetic environment and evolution. In: Evolution as a Process, ed. J. Huxley, A. C. Hardy and E. B. Ford, pp. 157-180. Allen and Unwin, London. owen, D. F. 1965a. Change in sex ratio in an African butterfly. Nature, 206, 744.

OWEN, D. F. 1965b. Density effects in polymorphic land snails. Heredity, 20, 312-315.

oWEN, D. F., AND Chanter, D. o. 1968. Population biology of tropical African butterflies. 2. Sex ratio and polymorphism in Danaus chrysippus. Rev. Zool. Bot. Afr., 78, 81-97.

PARR, M. J. 1965. A population study of a colony of imaginal Ischnura elegans (van der Linden) (Odonata: Coenagriidae) at Dale, Pembrokeshire. Field Studies, 2, 237-282. poulton, E. B. 1908. Essays on Evolution 1889-1907. 479 pp. Clarendon, Oxford. PunNet, R. C. 1915. Mimicry in butterfies. 159 pp. Cambridge, England.

SCHMIDT, R. s. 1958. Behavioural evidence on the evolution of Batesian mimicry. Brit. $\mathcal{J}$. Anim. Behav., 6, 129-138.

SHEPPARD, P. M. 1951. Fluctuations in the selective values of certain phenotypes in the polymorphic land snail Cepaea nemoralis (L.). Heredity, 5, 125-134.

SOUTHWARD, T. R. E. 1966. Ecologica methods. 391 pp. Methuen, London.

STRIDE, G. o. 1956. On the courtship behaviour of Hypolimnas misisppus L. (Lepidoptera, Nymphalidae), with notes on the mimetic association with Danaus chrysippus L. (Lepidoptera, Danaidae). Brit. 7. Anim. Behav., 4, 52-68.

STRIDE, G. o. 1957. Investigations into the courtship behaviour of the male of Hypolimnas misippus L. (Lepidoptera, Nymphalidae), with special reference to the role of visual stimuli. Brit. F. Anim. Behav., 5, 153-167.

STRIDE, G. o. 1958. Further studies on the courtship behaviour of African mimetic butterflies. Brit. 7. Anim. Behav., 6, 224-230. 